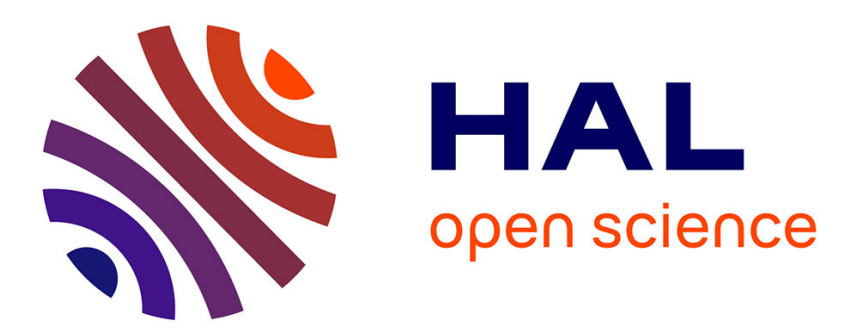

\title{
A simple method for background determination in small angle scattering experiments
}

F. Carsughi, D. d'Angelo, F. Rustichelli

\section{To cite this version:}

F. Carsughi, D. d'Angelo, F. Rustichelli. A simple method for background determination in small angle scattering experiments. Journal de Physique IV Proceedings, 1993, 03 (C8), pp.C8-515-C8-518. 10.1051/jp4:19938107 . jpa-00252238

\section{HAL Id: jpa-00252238 https://hal.science/jpa-00252238}

Submitted on 1 Jan 1993

HAL is a multi-disciplinary open access archive for the deposit and dissemination of scientific research documents, whether they are published or not. The documents may come from teaching and research institutions in France or abroad, or from public or private research centers.
L'archive ouverte pluridisciplinaire HAL, est destinée au dépôt et à la diffusion de documents scientifiques de niveau recherche, publiés ou non, émanant des établissements d'enseignement et de recherche français ou étrangers, des laboratoires publics ou privés. 


\title{
A simple method for background determination in small angle scattering experiments
}

\author{
F. CARSUGHI, D. D'ANGELO* and F. RUSTICHELLI
}

Istituto di Scienze Fisiche, Università di Ancona, Italy

${ }^{*}$ ENEL-CRTN, Milano, Italy

\begin{abstract}
The coherent signal of Small Angle Scattering superimposes to a flat background, which is given by incoherent scattering, by electronic noise and, sometimes, by radiation background around the instrument. In order to analyze the experimental data, the background level has to be taken into account and quite often theoretical estimations do not give values comparable to the experimental evidences. In this paper it is shown a new representation which allows in a simple way the background level determination; in particular, in a convenient plot, the experimental data are fitted by a straight line passing through the origin, the slope of which is equal to the fourth root of the background.
\end{abstract}

\section{INTRODUCTION}

If the background B is present, the asymptotic behaviour of the Small Angle Scattering (SAS) intensity $I$ is given by the so-called Porod law

$$
I=\frac{K}{Q^{4}}+B
$$

where $K$ is a constant related also to the specific surface of the scattering centres, $B$ the background and $Q$ the exchanged wave vector given by

$$
Q=\frac{4 \pi}{\lambda} \sin \theta
$$

being $\lambda$ and $2 \theta$ the incident radiation wavelength and the full scattering angle, respectively. 


\section{BACKGROUND DETERMINATION}

From eq. (1), one can derive

$$
\lim _{Q \rightarrow \infty} \sqrt[4]{I Q^{4}}=\lim _{Q \rightarrow \infty} \sqrt[4]{B Q^{4}+K}=\lim _{Q \rightarrow \infty} \sqrt[4]{B Q^{4}\left(1+\frac{K}{B Q^{4}}\right)} \cong Q \sqrt[4]{B}
$$

as for sufficiently large $Q\left(Q \gg \sqrt[4]{\frac{K}{B}}\right)$ the term $\frac{K}{B Q^{4}}$ becomes negligible as compared to unit, no matter how large the quantity $\frac{K}{B}$ is. Under this consideration the asymptotic behaviour in the $Q \sqrt[4]{I}$ vs $Q$ plot is represented by a straight line passing through the origin, being its slope the fourth root of the background value.

Like other quantitative information extracted from the SAS data by simple linear fits, with the procedure shown above, it is possible to determine, in a simple way, the background level.

\section{EXPERIMENTAL RESULTS}

In order to check the validity of this method, it was applied to SANS data of a virgin material and a turbine blade of IN $738 \mathrm{Ni}$-based Superalloy. The background level found by using the eq. (3) is also compared to that found by fitting the data in the $I Q^{4}$ vs $Q$ plot (Fig. 1), and the results are shown in Tab. 1, demonstrating the validity of the easier linear fit, which can be performed without any computer and in the same way used for Guinier radius determination.

It should be emphasized that the method here presented is an approximation of other routinely used, such as that in [1]; the main advantage is the representation that allows a quick determination of the background level in a very simple way without any computer calculation.

In conclusion, the eq. (3) can take the more general form

$$
\lim _{Q \rightarrow \infty} \sqrt[n]{I Q^{n}}=Q \sqrt[n]{I} \cong Q \sqrt[n]{B}
$$

being $n$ the exponent of the asymptotic law (for example, $n=3$ in infinite slit geometry diffractometers). 

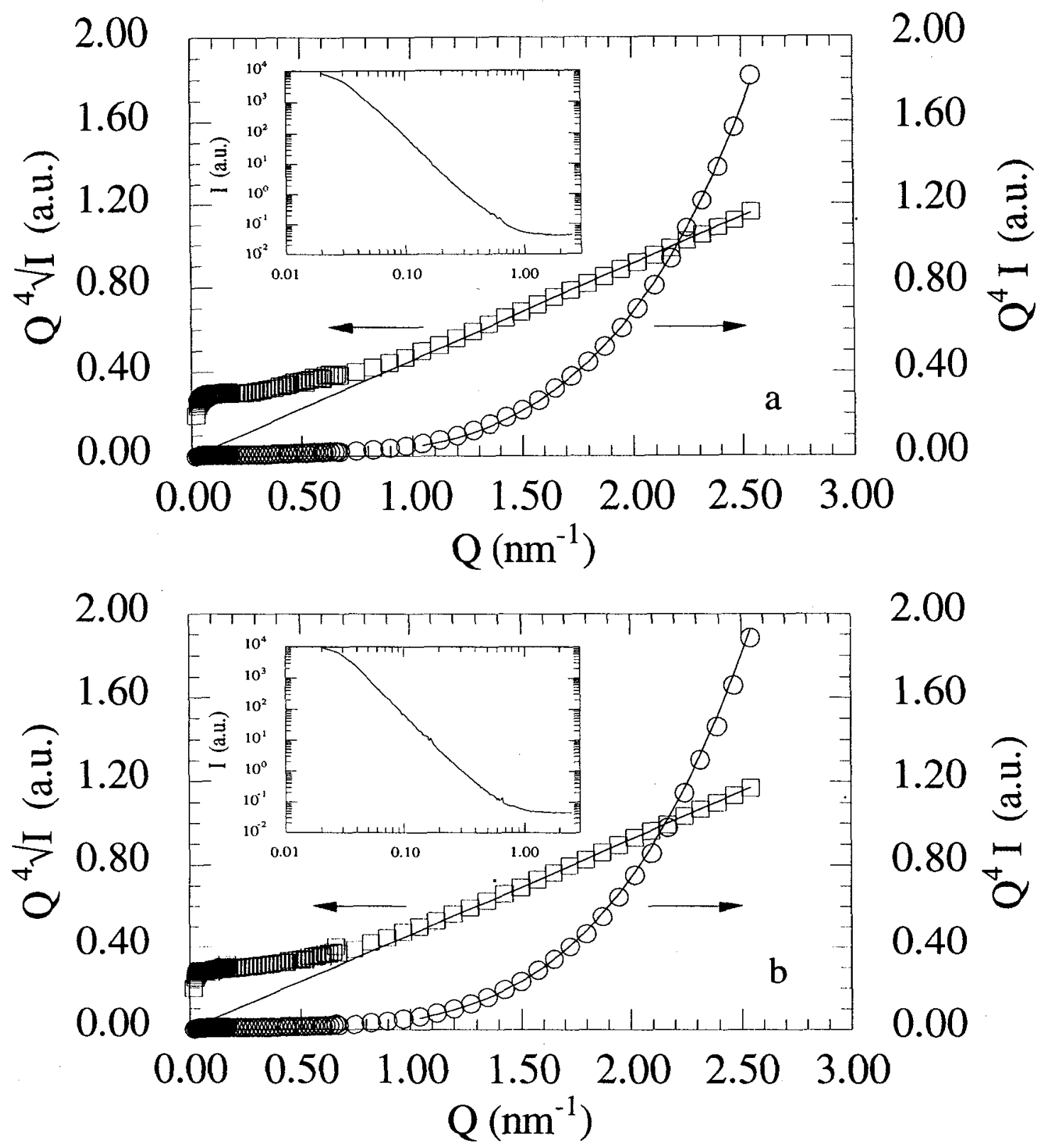

1. Best fits of the experimental intensities of IN 738 Ni-based Superalloy for background determination by using both the linear (right side) and the power fit (left side); virgin material (a) and turbine blade (b). 
Tab. 1

\begin{tabular}{c|c|c} 
BACKGROUND & Virgin material & Turbine Blade \\
\hline power fit & $4.24 \pm 0.02 \cdot 10^{-2}$ & $4.47 \pm 0.02 \cdot 10^{-2}$ \\
linear fit & $4.37 \pm 0.01 \cdot 10^{-2}$ & $4.58 \pm 0.01 \cdot 10^{-2}$
\end{tabular}

1. Background level of the SANS intensities of the IN $738 \mathrm{Ni}$-based Superalloy: virgin material and turbine blade. The background was obtained by using the linear and the power fit.

\section{REFERENCES}

[1] J.P.Cotton, Neutron, X-ray and Light Scattering, Ed. by P.Lindner and Th.Zemb (1991), 19. 